\title{
USING THE ANALYTIC HIERARCHY PROCESS TO CREATE AN EROSION RISK MAP. A CASE STUDY IN MALAKASIOTIKO STREAM, TRIKALA PERFECTURE
}

\author{
Bathrellos G. ${ }^{1}$, and Skilodimou H. $^{1}$ \\ ${ }^{1}$ National and Kapodistrian University of Athens, Faculty of Geology and Geoenvironment, \\ Department of Geography - Climatology,gbathrellos@geol.uoa.gr,hskilodimou@euof.uoa.gr
}

\begin{abstract}
This study is aimed at the evaluation of the erosion risk at the drainage basin of Malakasiotiko stream in Trikala prefecture, using a Geographic Information System (GIS). A database from six factors that influence erosion namely slope, lithology, drainage density, tectonic features density, land use and rainfall inserted into GIS. Each factor was grouped in various classes. A method known as Analytic Hierarchy Process (AHP) was applied to rate the individual classes of each factor and weight the impact of one factor against the other in order to determination their importance to erosion process. The results of the AHP application in combination with GIS techniques were used to estimate the overall erosion risk and create the erosion risk map. The study area was divided into three zones of erosion risk. High erosion risk zones are mostly located on the northwest, west and south parts of the drainage basin of Malakasiotiko stream. The erosion risk map of the study area can be a useful geologic and geomorphologic criterion for the land use planning.
\end{abstract}

Key words: GIS, multi-criteria analysis, erosion, land-use planning.

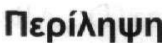

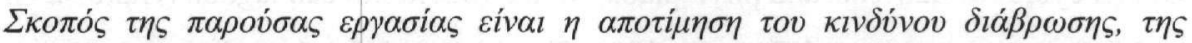

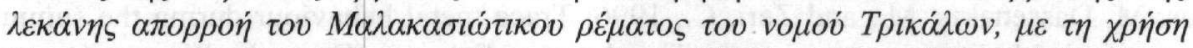

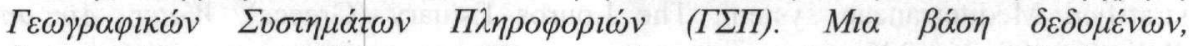

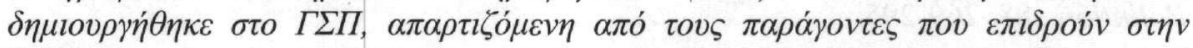

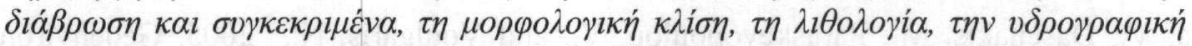

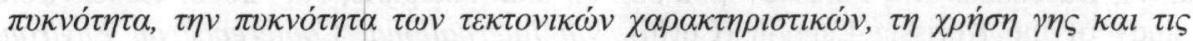

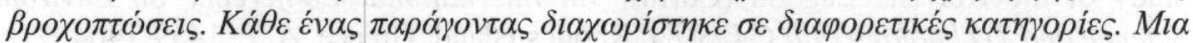

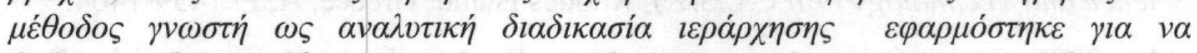

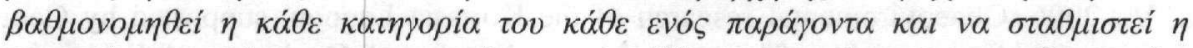

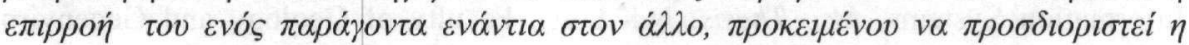

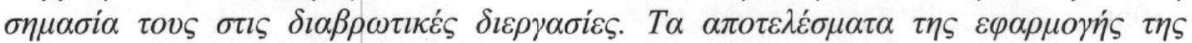

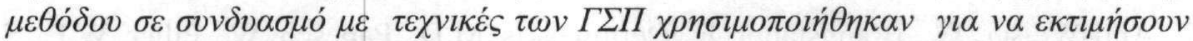

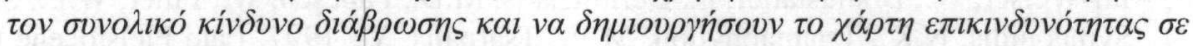

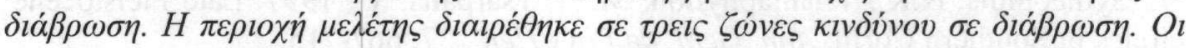

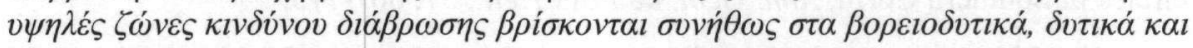

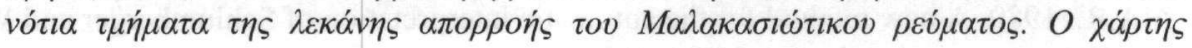




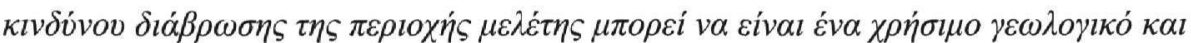

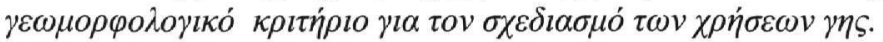

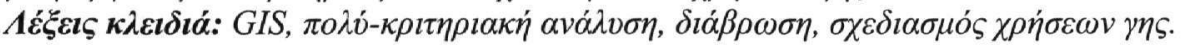

\section{Introduction}

Erosion is a natural geomorphic process that is active during the whole geological time and formed the earth's surface. However, nowadays erosion is considered a global issue causing significant environmental problems. Moreover, the human activities trigger and accelerate the erosive processes (Julien 1998). The erosion has long-term effects on the quality of cultivable soil and the agricultural productivity, the quality of waters, the transport of sediments and on the changes in river channel and impacts on flooding (Morgan 1995). Particularly, in mountain areas the erosion from unstable and loose geological material leads to gully erosion and mass movement of soil and rocks (Lee 2003).

In order to protect the land and minimize the erosion various management practices are used. The spatial distribution of the areas susceptible to erosion and the assessing of risk erosion have an essential importance in the land planning strategies and agricultural management (Mati et al. 2000, Sujatha et al. 2000, Zink et al. 2001, Shrestha et al. 2004).

Geographic Information System (GIS) techniques assist the spatial analysis of a multidimensional phenomenon such as erosion. The aim of this study was to determine the areas susceptible to erosion and to generate an erosion risk map using GIS in the drainage basin of Malakasiotiko stream in the Trikala prefecture. An erosion risk map relies on a rather complex knowledge of erosion processes and their controlling factors. It is also on such variable territory a matter of choosing a suitable methodology. In this study we used a method known as Analytic Hierarchy Process (Saaty 1988) that was applied to the study area.

The Analytic Hierarchy Process (AHP) is a decision approach designed to aid in the solution of complex multiple criteria problems (Drake 1998, Saaty and Vargas 2001, Ayalew et al. 2004). The AHP method starts in this research with the comparison of data layers corresponding to factors that interact in the erosion and it involves assigning weights for each class of a particular factor using a pair-wise comparison matrix. Then it computes weights to the factors themselves. The final step of this method is the combination of all weighted layers into a singe erosion risk map.

\section{Materials and Methods}

\subsection{Study location}

The Malakasiotiko stream is one of the tributaries of Pineios River in Western Thessaly. The drainage basin of Malakasiotiko stream is located in the northwestern part of the mountainous zone of Trikala Prefecture. Figure 1 shows the location of the study area.

The drainage network of Malakasiotiko stream consists of 2,083 channels and has a channel length of a $1428 \mathrm{~km}$. It flows from northwest to southeast and drains areas of the Southern mountain range of Pindos, as well as the mountain of Hasia. The drainage basin of Malakasiotiko stream covers $337 \mathrm{~km}^{2}$ and its altitude varies from 276 to $1974 \mathrm{~m}$ above the mean sea level (m.s.l.). The climate is Mediterranean with a rainy period that begins in October and ends in May. The mean annual precipitation in the area fluctuates from 894.3 to $1188.4 \mathrm{~mm}$.

\subsection{Data preparation}

A GIS database has been developed using ArcGIS ver. 9.0 software. The input data used for erosion risk mapping have been recorded and saved as separate layers in the database. All the data layers are in vector format, transformed in grids with cell size 100x100 meters. 


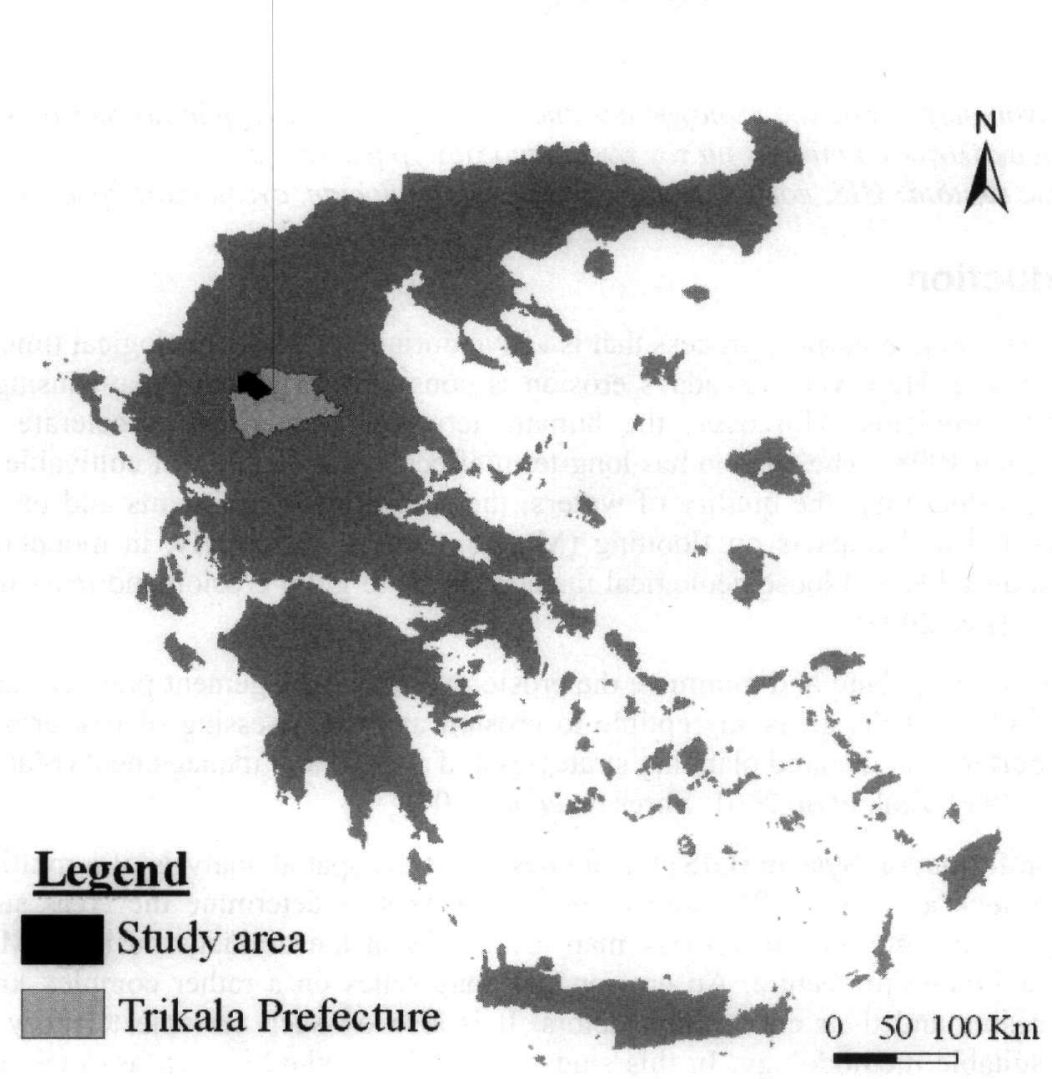

Figure 1 - The study area location

The factors which were taken into account for the creation of the erosion risk map have been based on the availability of published studies in the literature (Vaidyanathan et al. 2002, Lee 2003, Svorin 2003). These factors are: slope, lithology, drainage density, tectonic features density, land use and rainfall.

\subsubsection{Thematic maps}

Slope. The information on slope was obtained from six topographical maps (scale 1:50,000) developed by Hellenic Military Geographical Service. The contour map ( $20 \mathrm{~m}$ interval) and the trigonometric points were manually digitized and a digital elevation model (DEM) was generated using the capabilities of 3D Analyst extension. The slope map was derived from DEM and the slopes were grouped in five classes: $0^{\circ}-10^{\circ}, 10^{\circ}-20^{\circ}, 20^{\circ}-30^{\circ}, 30^{\circ}-40^{\circ},>40^{\circ}$ (Fig. 2).

Lithology. The rock type and the structural state of rock types have important influence on the erosion process. In addition mixed lithologies are more susceptible to erosive force and demonstrate a high frequency of mass movements (Vaidyanathan et al. 2002). According to 1:50,000 geological maps (Aubouin 1961, Koumantakis and Mataragas 1980) and 1:100,000 geological map (Bathrellos 2005) the study area is composed of:

- Quaternary formations: alluvial deposits (AL), talus cones and scree (TC) and Pleistocene talus cones and scree deposits (PLTD),

- Pliocene limnic and fluviatil deposits (PFD),

- Molasses formations: clastic formations of Heptachorion-Kipourion Series (HS) and clastic formations of Krania Series (KS), 


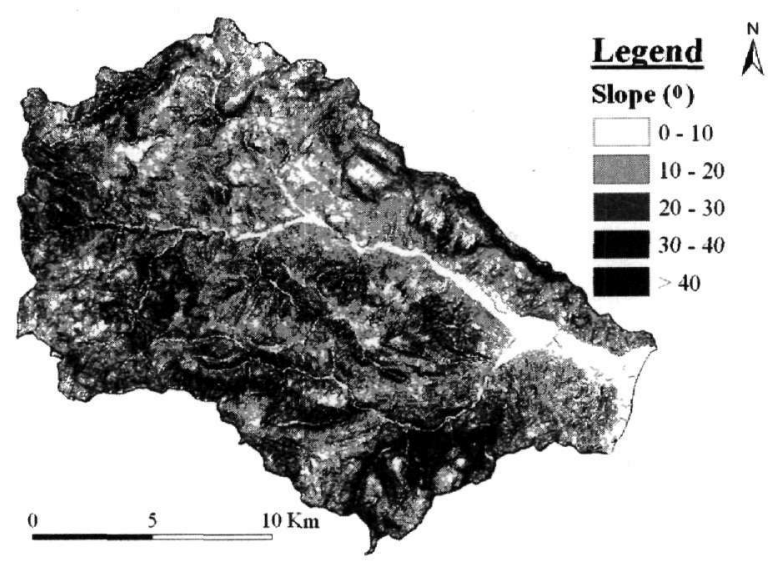

Figure 2 - The slope map

- Flysch: flysch of Pindos Zone (FPL) and First Flysch of Pindos Zone (FFLP)

- Cretaceous limestones of Pindos Zone (CLP),

- Cherts of Pindos Zone (CP),

- Ophiolites $(\mathrm{O})$.

The lithological formation of the study area is presented in figure 3 .

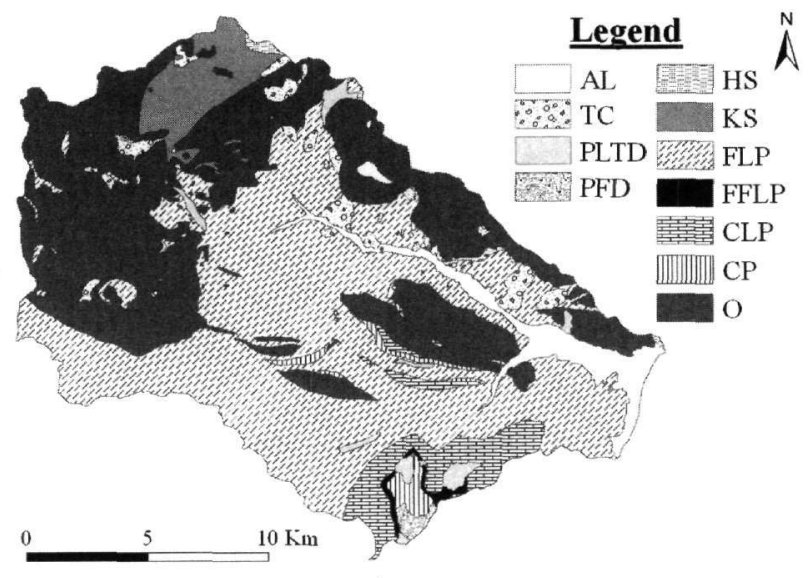

Figure 3 - The geological map

Drainage density. The digitized drainage network map of the study area was derived from the topographical sheets (Fig. 4) and was used as input in the database. Drainage density is the sum of stream lengths per unit area. The drainage density map was prepared after calculating the density of each cell $(100 \times 100 \mathrm{~m})$ using GIS capabilities. The values obtained rage from 0 to $3.5 \mathrm{~km}^{-1}$, which were finally grouped into five classes: $0.00-0.70,0.71-1.4,1.41-2.1,2.11-2.8,2.81$ 3.5 .

Tectonic features density. The tectonic features map of the study area including thrusts, and lineaments (Fig. 5) was generated based on the 1:50,000 geological maps (Aubouin, 1961, Koumantakis and Mataragas, 1980) and on 1:100,000 lineament map compiled by Bathellos (2005). The linear features were vectorized and the tectonic features density (TFD) map was prepared in the similar way as the drainage density map by computing the density of each cell. The density values $\left(\mathrm{km}^{-1}\right)$ were classified into five classes: $0.00-0.65,0.66-1.31,1.32-1.97,1.98$ $2.63,2.64-3.2$. 


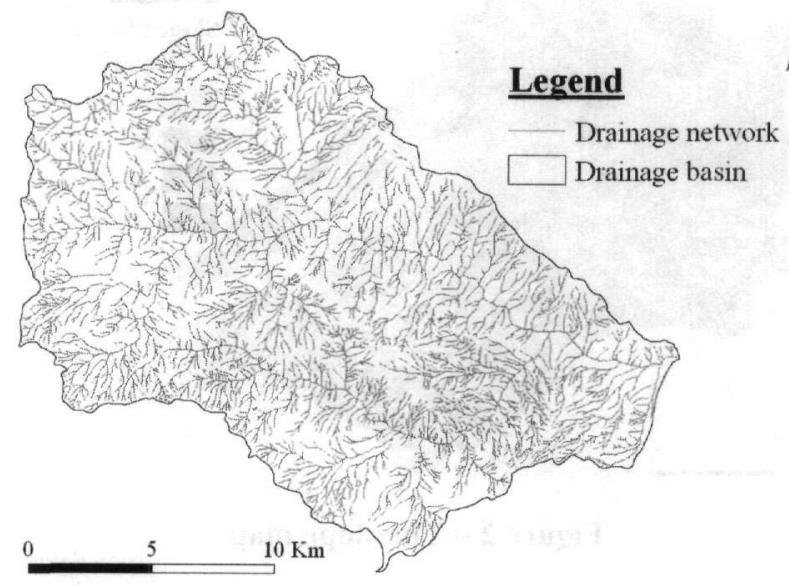

Figure 4 - The drainage network of Malakasiotiko stream

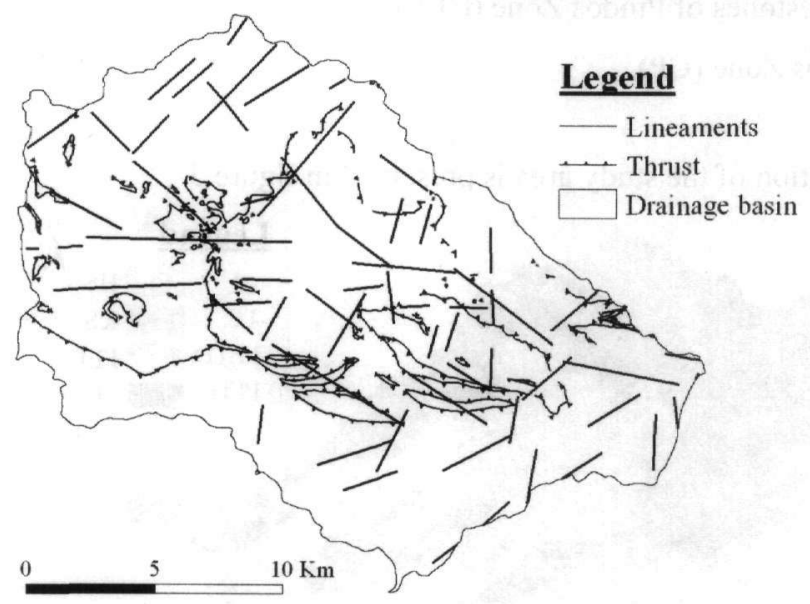

Figure 5 - The tectonic features map

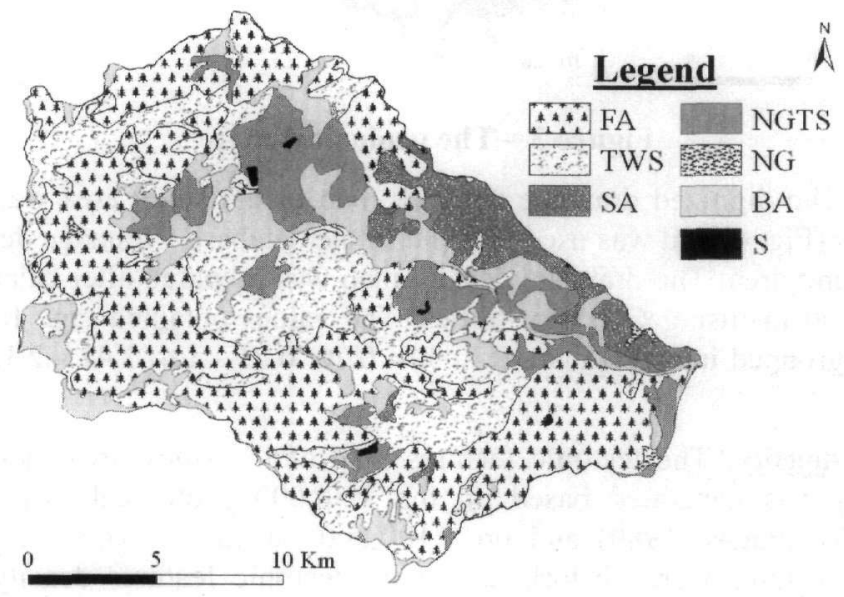

Figure 6 - The land use map 
Land use. The digitized land use map of the area was obtained from the program CORINE (Bossard, et al. 2000). Seven classes were identified: forest areas (FA), transitional woodland/shrub (TWS), shrubby areas (SA), natural grassland with trees and shrubs (NGTS), natural grassland (NG), barren areas (BA) and settlements (S) (Fig. 6).

Rainfall. Rainfall data were obtained from a 30-year record up to the year 2003 from three meteorological stations of the Ministry of Environment Planning and Public Works and the Ministry of Agriculture. The mean annual precipitations of these stations are: 894.3, 1061.7 and $1188.4 \mathrm{~mm}$. According to this the entire area was divided into three parts using the Thiessen polygons methodology. The rainfall map is shown in figure 7 .

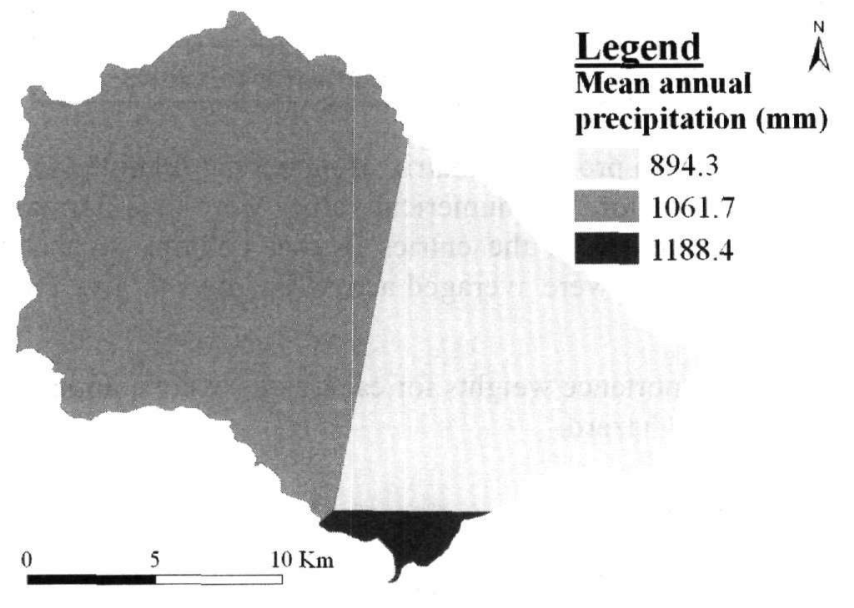

Figure 7 - The rainfall map

\subsubsection{The Analytic Hierarchy Process (AHP)}

As it was mentioned before the above data were incorporated in a GIS environment using the AHP. According to the spatial-AHP method (Harrald et al. 2004, Silleos et al. 2004, Johnson and Christopherson 2005) the data derived from the map were arranged in a decision hierarchy. A three-level hierarchy decision process is described below:

Level 1: the overall goal of this application was the erosion hazard assessment and is present at the top level of hierarchy.

Level 2: the second level represents the factors which were identified to achieve the overall goal. The slope, lithology, drainage density, tectonic features density, land use and rainfall of the study area were used to constitute the second level.

Level 3: The above mentioned classes (sub factor) of each factor are represented at the third level of hierarchy.

Since the hierarchy has been structured the next step was to assign the priorities of sub factors at the third level and then of the factors at second level. The relative importance weights were computed by using pair-wise comparisons of sub factors. The relative weights are opinion based scores which determine the degree of relative importance amongst the sub factors. The pair-wise comparison process in this study performed using a nine point scale of Saaty (1988). The meaning of each scale measurement is explained in table 1 . 
Table 1 - Scale of level of importance between two factors

\begin{tabular}{|l|l|}
\hline \multicolumn{1}{|c|}{ Numerical value } & \multicolumn{1}{c|}{ Level of importance } \\
\hline 1 & Equal \\
\hline 2 & Moderately \\
\hline 5 & Strongly \\
\hline 7 & Very strongly \\
\hline 9 & Extremely \\
\hline $2,4,6,8$ & Intermediates values \\
\hline
\end{tabular}

By using the pair-wise comparison process, a matrix of numerical relative rankings (between 1 and 9) was generated for each sub factor. The numerical values were then normalized by diving each entry in the column by the sum of all the entries in that column, so that they sum up to 1 . Following normalization the values were averaged across the rows to give the relative importance weight for each sub factor.

In the same way the relative importance weights for each factor were computed. The final step was the overall estimation of erosion hazard.

\section{Results and discussion}

\subsection{Rating of the sub factors}

Since each class (sub factor) of the factors has different importance to the erosion process its rating was considered necessary. The relative importance weights $\left(\mathrm{RW}^{3}\right)$ for each sub factor at the third level of hierarchy by the pair-wise comparisons are displayed in Tables 2 - 6 .

Table 2 - Pair-wise comparisons of the sub factors of slope

\begin{tabular}{|l|l|l|l|l|l|l|}
\hline \multicolumn{1}{|c|}{ Slope } & & & & & & $\mathrm{RW}^{3}$ \\
\hline & $0^{0}-10^{0}$ & $10^{0}-20^{0}$ & $20^{0}-30^{0}$ & $30^{0}-40^{0}$ & $>40^{0}$ & \\
\hline $0^{0}-10^{0}$ & 1 & $1 / 3$ & $1 / 5$ & $1 / 7$ & $1 / 9$ & 0.035 \\
\hline $10^{0}-20^{0}$ & 3 & 1 & $1 / 3$ & $1 / 5$ & $1 / 7$ & 0.068 \\
\hline $20^{0}-30^{0}$ & 5 & 3 & 1 & $1 / 3$ & $1 / 5$ & 0.134 \\
\hline $30^{0}-40^{0}$ & 7 & 5 & 3 & 1 & $1 / 3$ & 0.260 \\
\hline$>40^{0}$ & 9 & 7 & 5 & 3 & 1 & 0.503 \\
\hline
\end{tabular}

Table 3 - Pair-wise comparisons of the sub factors of lithology

\begin{tabular}{|c|c|c|c|c|c|c|c|c|c|c|c|c|}
\hline Lithology & & & & & & & & & & & & $\mathrm{RW}^{3}$ \\
\hline & CPL & $\mathrm{CP}$ & $\mathrm{O}$ & FFLP & FLP & HS & KS & PFD & PLTD & $\mathrm{TC}$ & $\mathrm{AL}$ & \\
\hline CPL & 1 & $1 / 2$ & $1 / 4$ & $1 / 5$ & $1 / 6$ & $1 / 7$ & $1 / 7$ & $1 / 8$ & $1 / 8$ & $1 / 9$ & $1 / 9$ & 0.013 \\
\hline $\mathrm{CP}$ & 2 & 1 & $1 / 3$ & $1 / 4$ & $1 / 5$ & $1 / 6$ & $1 / 6$ & $1 / 7$ & $1 / 7$ & $1 / 8$ & $1 / 8$ & 0.017 \\
\hline $\mathrm{O}$ & 4 & 3 & 1 & $1 / 2$ & $1 / 3$ & $1 / 5$ & $1 / 5$ & $1 / 6$ & $1 / 6$ & $1 / 7$ & $1 / 7$ & 0.027 \\
\hline FFLP & 5 & 4 & 2 & 1 & 12 & $1 / 4$ & $1 / 4$ & $1 / 5$ & $1 / 5$ & $1 / 6$ & $1 / 6$ & 0.036 \\
\hline FLP & 6 & 5 & 3 & 2 & 1 & $1 / 3$ & $1 / 3$ & $1 / 4$ & $1 / 4$ & $1 / 5$ & $1 / 5$ & 0.050 \\
\hline
\end{tabular}




\begin{tabular}{|l|r|r|r|r|r|r|r|r|r|r|r|r|}
\hline Lithology & & & & & & & & & & & & $\mathrm{RW}^{3}$ \\
\hline HS & 7 & 6 & 5 & 4 & 3 & 1 & $1 / 2$ & $1 / 3$ & $1 / 3$ & $1 / 4$ & $1 / 4$ & 0.078 \\
\hline KS & 7 & 6 & 5 & 4 & 3 & 2 & 1 & $1 / 2$ & $1 / 2$ & $1 / 3$ & $1 / 3$ & 0.093 \\
\hline PFD & 8 & 7 & 6 & 5 & 4 & 3 & 2 & 1 & $1 / 2$ & $1 / 3$ & $1 / 3$ & 0.121 \\
\hline PLTD & 8 & 7 & 6 & 5 & 4 & 3 & 2 & 2 & 1 & $1 / 2$ & $1 / 2$ & 0.143 \\
\hline TC & 9 & 8 & 7 & 6 & 5 & 4 & 3 & 3 & 2 & 1 & $1 / 2$ & 0.196 \\
\hline AL & 9 & 8 & 7 & 6 & 5 & 4 & 3 & 3 & 2 & 2 & 1 & 0.226 \\
\hline
\end{tabular}

Table 4 - Pair-wise comparisons of the sub factors of DD and TFD

\begin{tabular}{|l|l|l|l|l|l|l|}
\hline $\mathrm{DD}\left(\mathrm{km}^{-1}\right)$ & & & & & & \\
\hline & $0.0-0.7$ & $0.71-1.4$ & $1.41-2.1$ & $2.11-2.8$ & $2.81-3.5$ & \\
\hline $0.0-0.7$ & 1 & $1 / 2$ & $1 / 5$ & $1 / 6$ & $1 / 9$ & 0.051 \\
\hline $0.71-1.4$ & 2 & 1 & $1 / 3$ & $1 / 5$ & $1 / 7$ & 0.078 \\
\hline $1.41-2.1$ & 5 & 3 & 1 & $1 / 3$ & $1 / 5$ & 0.154 \\
\hline $2.11-2.8$ & 6 & 5 & 2 & 1 & $1 / 3$ & 0.246 \\
\hline $2.81-3.5$ & 9 & 7 & 6 & 3 & 1 & 0.520 \\
\hline $\mathrm{TFD}\left(\mathrm{km}^{-1}\right)$ & & & & & & \\
\hline & $0.00-0.65$ & $0.66-1.31$ & $1.32-1.97$ & $1.98-2.63$ & $2.64-3.2$ & \\
\hline $0.00-0.65$ & 1 & $1 / 2$ & $1 / 5$ & $1 / 6$ & $1 / 9$ & 0.051 \\
\hline $0.66-1.31$ & 2 & 1 & $1 / 3$ & $1 / 5$ & $1 / 7$ & 0.078 \\
\hline $1.32-1.97$ & 5 & 3 & 1 & $1 / 3$ & $1 / 5$ & 0.154 \\
\hline $1.98-2.63$ & 6 & 5 & 2 & 1 & $1 / 3$ & 0.246 \\
\hline $2.64-3.2$ & 9 & 7 & 6 & 3 & 1 & 0.520 \\
\hline
\end{tabular}

Table 5 - Pair-wise comparisons of the sub factors of land use

\begin{tabular}{|l|l|l|l|l|l|l|l|l|}
\hline \multicolumn{1}{|c|}{ Land use } & & & & & & & & $\mathrm{RW}^{3}$ \\
\hline & $\mathrm{S}$ & FA & TWS & SA & NGTS & NG & BA & \\
\hline S & 1 & 1 & $1 / 2$ & $1 / 3$ & $1 / 5$ & $1 / 7$ & $1 / 9$ & 0.024 \\
\hline FA & 1 & 1 & $1 / 2$ & $1 / 3$ & $1 / 5$ & $1 / 7$ & $1 / 9$ & 0.031 \\
\hline TWS & 2 & 2 & 1 & $1 / 3$ & $1 / 5$ & $1 / 6$ & $1 / 7$ & 0.051 \\
\hline SA & 3 & 3 & 3 & 1 & $1 / 3$ & $1 / 5$ & $1 / 7$ & 0.086 \\
\hline NGTS & 5 & 5 & 5 & 3 & 1 & $1 / 3$ & $1 / 5$ & 0.155 \\
\hline NG & 7 & 7 & 6 & 5 & 3 & 1 & $1 / 3$ & 0.250 \\
\hline BA & 9 & 9 & 7 & 7 & 5 & 3 & 1 & 0.404 \\
\hline
\end{tabular}


Table 6 - Pair-wise comparisons of the sub factors of rainfall

\begin{tabular}{|l|l|l|l|l|}
\hline \multicolumn{1}{|c|}{ Rainfall $(\mathrm{mm})$} & & & & $\mathrm{RW}^{3}$ \\
\hline & 894.3 & 1061.7 & 1188.4 & \\
\hline 894.3 & 1 & $1 / 7$ & $1 / 9$ & 0.054 \\
\hline 1061.7 & 7 & 1 & $1 / 3$ & 0.123 \\
\hline 1188.4 & 9 & 3 & 1 & 0.356 \\
\hline
\end{tabular}

The values of the relative weights for each sub factor were calculated between 0 and 1 and add up to 1 . All the data layers were integrated in a GIS environment and for each sub factor the corresponding relative weight was assigned.

\subsection{Rating of the factors}

The next step in this study was to identify the different significance of the factors on the erosion process. The rating of factors was accomplished in a similar way as for the sub factors one via the pair-wise comparison. The relative importance weights $\left(\mathrm{RW}^{2}\right)$ for each factor at the second level of hierarchy are shown in Table 7.

Table 7 - Pair-wise comparisons of the factors

\begin{tabular}{|l|l|l|l|l|l|l|l|}
\hline Factor & & & & & & & RW $^{2}$ \\
\hline & Rainfall & Land use & TFD & DD & Lithology & Slope & \\
\hline Rainfall & 1 & $1 / 3$ & $1 / 5$ & $1 / 6$ & $1 / 7$ & $1 / 9$ & 0.028 \\
\hline Land use & 3 & 1 & $1 / 2$ & $1 / 3$ & $1 / 5$ & $1 / 7$ & 0.057 \\
\hline TFD & 5 & 2 & 1 & $1 / 2$ & $1 / 3$ & $1 / 5$ & 0.096 \\
\hline DD & 6 & 3 & 2 & 1 & $1 / 3$ & $1 / 5$ & 0.133 \\
\hline Lithology & 7 & 5 & 3 & 3 & 1 & $1 / 3$ & 0.237 \\
\hline Slope & 9 & 7 & 5 & 5 & 3 & 1 & 0.450 \\
\hline
\end{tabular}

As in the case of sub factors the numerical values of the relative weights fluctuate from 0 to 1 and sum up 1.

\subsection{The erosion risk map}

The implementation of the AHP results for all the maps was achieved in GIS environment by the capabilities of the Spatial Analyst extension. The rasterized maps were combined in order to estimate the overall erosion risk. The overall score was determined by the following mathematical operator:

Equation 1 - Formula for overall score

$$
\text { Erosion risk } \equiv \sum_{i=1}^{N^{2}}\left[\left(R W_{i}^{2}\right)\left(R W_{i j}^{3}\right)\right]
$$

where $\mathrm{N}^{2}=$ the number of the second level factor, $\mathrm{RW}_{\mathrm{i}}{ }^{2}=$ relative weight of the second level factor $i, \mathrm{RW}_{i j}{ }^{3}=$ relative weight of the third level sub factor $j$ of the second level factor $i$. 
At the final step the erosion risk map was produced with continuous numerical values. The division of these values into risk classes was not unproblematic (Ayalew et al. 2004) as there are no statistical rules which can guide to categorize continuous data automatically. In this paper we took into consideration the quantliles system of classifiers because it was the method that best suits the objectives of our study. The erosion risk map was converted into a map with three classes: low, medium and high. These categories corresponded to three relative scales of erosion risk assessment; the higher value representing the higher erosion hazard (Fig 8). The low, medium and high erosion risk zones represent the $37.9 \%, 34.5 \%$ and $27.6 \%$ respectively of the entire study area.

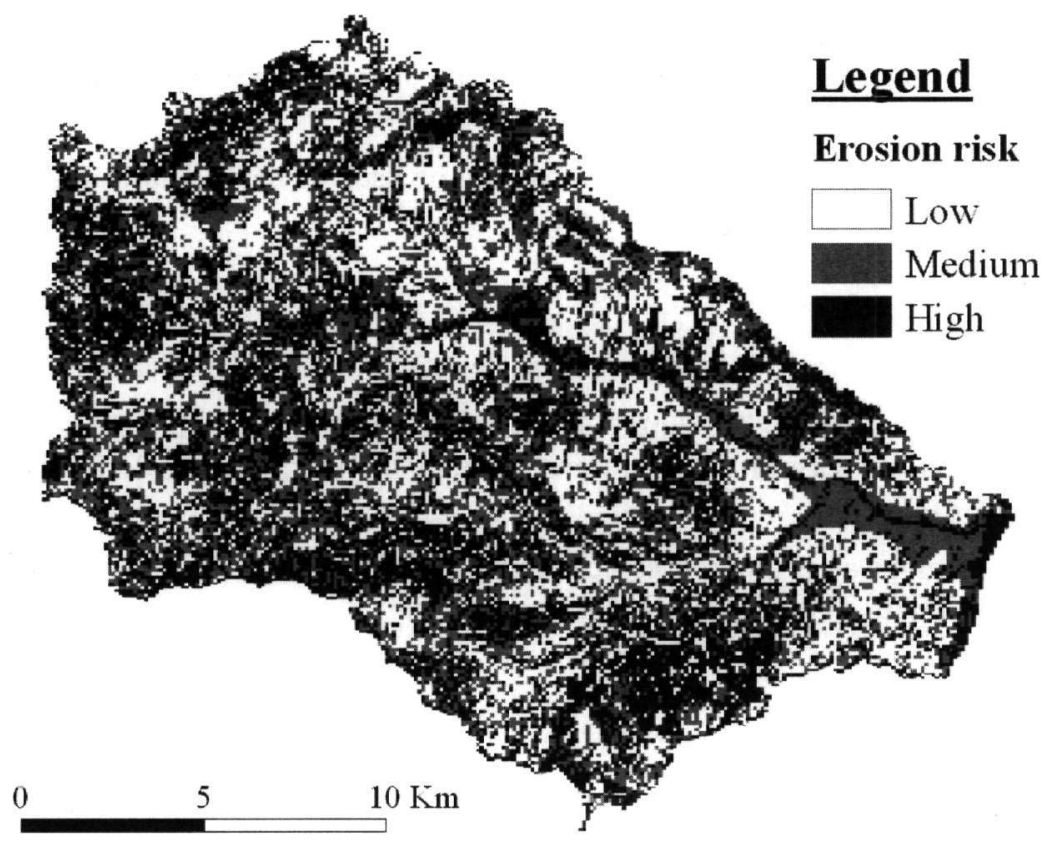

Figure 8 - The erosion risk map

The erosion risk map shown in figure 8 is strongly related with slope and lithology, which was expected due to highest weighting being given to them. The areas with high risk of erosion are mostly located in the northwest, west and south parts of the drainage basin of Malakasiotiko stream. High erosion risk is found at the Quaternary and Pliocene formations. Some isolated zones of high erosion in the central part of the drainage basin are probably attributed to drainage and tectonic feature density. The results of the erosion map show that especially barren lands generally found on steep slopes and hilly mountainous areas have the highest erosion risk.

The erosion risk map represents a powerful display of information in risk assessment for conservation planning. Its capability to spot areas of high erosion risk for various land use alternatives is important for successful land use management. In many cases the areas susceptible to erosion coincide with high landslide susceptibility (Wachal and Hudak 2000). Planners could use the areas of high susceptibility to erosion to identify areas prone to landslides. The results of the erosion risk map of the study area may be used as basic data to assist the soil conservation master plans and the land-use planning.

Besides, the application of the AHP within the study area provides many advantages. Data requirements were not too complex and it was compatible with a GIS. The AHP makes the selection process very obvious (Drake, 1998); it is easy to use and allows a systematic method for comparison and weighting of multiple criteria by decision-makers. Consequently, the application of the AHP had a distinct benefit when attempting to produce erosion risk map of the study area. 


\section{Conclusions}

In the study area, the spatial distribution of areas susceptible to erosion is a result of the interaction of various factors. In this work six factors: slope, lithology, drainage density, tectonic features density, land use and rainfall were considered to obtain the erosion risk map that was created in function of the determination and the correlation of the role of these factors.

The Analytic Hierarchy Process (AHP) method was applied in order to assign the weights of individual classes of each factor and of the factors themselves. The results of AHP application in combination with GIS techniques were used to produce the erosion risk map.

The study area was divided into three zones of erosion risk namely low (38.9 \%), medium $(34.5 \%)$ and high $(26.6 \%)$. The area which is at high scale of erosion risk lies on the northwest, west and south parts of the drainage basin of Malakasiotiko stream.

The results of the erosion risk map of the study area may be used as basic data to assist the soil conservation master plans and the land-use planning.

\section{References}

Aubouin, J., 1961. Geological map, Pramanta sheet, scale 1:50000, IGME publications.

Ayalew L, Yamagishi H., and Ugawa N., 2004. Landslide susceptibility mapping using GIS-based linear combination, the case in Tsugawa area of Agano River, Niigata Perfecture, Japan, Lanslides 1, 73-81.

Bathrellos, G., 2005. Geological, geomorphological and geographic study of urban areas in Trikala Prefecture - Western Thessaly, PhD Thesis, National and Kapodistrian Univ. Athens, Greece, $567 \mathrm{pp}$.

Bossard, M., Feranec, J., and OtaheL, J., 2000. CORINE land cover technical guide - Addendum 2000, European Environment Agency, Copenhagen, 104pp.

Drake, P.R., 1998. Using the Analytic Hierarchy Process in Engineering Education, Int. J. Enging. Ed., 14(3), $191-196$.

Harrald, J., Renda-Tanali, I., Shaw, G., Rubin, C., and Yeletaysi, S., 2004. Review of risk based prioritization/decision making methodologies for dams, Institute for Crisis, Disaster and Risk Management, George Washington University, 42pp.

Johnson, P., and Christopherson, G., 2005. Using the Analytic Hierarchy process to create a wildfire model, ESRI International User Conference Proceeding, http://gis.esri.com/library/userconf/proc05/papers/pap1403.pdf

Julien, P.Y., 1998. Erosion and Sedimentation, Cambridge University Press 280 pp.

Koumantakis, J., and Mataragas, D., 1980. Geological map, Panagia sheet, scale 1:50000, IGME publications.

Lee, S., 2003. Soil erosion assessment and its verification using the Universal Soil Loss Equation and Geographic Information System: a case study at Boun, Korea, Environmental Geology, $45,457-465$.

Mati, B.M., Morgan, R.P.C, Gichuk, F.N., Quintor, J.N., Brewer, T.R., and Liniger, H.P., 2000. Assessment of erosion hazard with the USLE and GIS: A case study of the Upper Ewaso $\mathrm{Ng}$ 'iro North basin of Kenya, International Journal of Applied Earth Observation and Geoinformation 2 (2), 78-86.

Morgan, R.P.C., 1995. Soil Erosion and Conservation, Longman, 198pp. 
Saaty, T., and Vargas, L., 2001 Models, methods, concepts and applications of the Analytic Hierarchy process, Kluwer's International Series, 352pp.

Saaty, T., 1988. The Analytic Hierarchy Process: planning, priority setting, resource allocation, RWS publications, Pittsburgh, 287pp.

Shrestha, D.P., Zinck, J.A., and Van Ranst, E., 2004. Modelling land degradation in the Nepalese Himalaya, Catena, 57, 135 - 156.

Silleos, G., Moutziki, E., and Perakis, K., 2004. Development of an algorithm for solving a linear model based on weighted multi-criteria for spatial data analysis applications, Geographies, $8,79-88$.

Sujatha, G., Dwivedi, R.S., Sreenivas, K., and Venkataratnam, L., 2000. Mapping and monitoring of degraded lands in part of Jaunpur district of Uttar Pradesh using temporal spaceborne multispectral data, Int. J. Remote Sensing 21(3), 519-531.

Svorin, J., 2003. A test of three soil erosion models incorporated into a geographical information system, Hydrol. Process, 17, 967-977.

Vaidyanathan, N.S., Sharma, G., Sinha, R., and Dikshit, O., 2002. Mapping of erosion intensity in the Garhwal Himalaya, Int. J. Remote Sensing 23(20), 4125-4129.

Wachal, D., and Hudak, P., 2000. Mapping landslide susceptibility in Travis County, Texas, USA, GeoJournal, 51, 245-253.

Zinck, J.A., Lopez, J., Metternicht, G., Shrestha, D.P., and Vazquez-Salem, L., 2001. Mapping and modelling mass movements and gullies in mountainous areas using remote sensing and GIS techniques, International Journal of Applied Earth Observation and Geoinformation 3 (1), 43-53. 